\title{
PENINGKATAN KUALITAS DODOS DENGAN VARIASI TEMPERATUR AUSTENISASI DAN MEDIA QUENCHING
}

\author{
Martin Doloksaribu dan Eva Afrilinda \\ Balai Besar Logam dan Mesin, Kementerian Perindustrian \\ Jalan Sangkuriang Nomor 12 Bandung 40135 \\ Email: martin-d@kemenperin.go.id, evaafrilinda@yahoo.com
}

\begin{abstract}
Abstrak
Untuk meningkatkan umur pakai dodos dapat dilakukan dengan proses austenisasi pada temperatur yang tertentu dan kemudian pendinginan cepat (quenching) dengan media yang sesuai. Dilakukan proses perlakuan panas perlakuan panas dengan variasi temperatur pemanasan yaitu 700, 800 dan $900^{\circ} \mathrm{C}$ dengan waktu penahanan (holding time) adalah 60 menit dan kemudian di-quenching dengan media larutan garam, air dan oli. Nilai kekerasan tertinggi yaitu 701,1 HV didapat pada temperatur austenisasi $900^{\circ} \mathrm{C}$ dengan media larutan garam dengan struktur yang terbentuk adalah martensit dan perlit.
\end{abstract}

Kata Kunci : dodos, perlakuan panas, media quenching, kekerasan

\begin{abstract}
Increasing the life time of dodos can be achieved byaustenization and quenching method with measureable temperature and appropriatequenching media. Specimens are heat treated on 700, 800 and $900^{\circ} \mathrm{C}$,hold for 1 hour and then quenched onbrine, water and oil. Austenization temperature on $900^{\circ} \mathrm{C}$ with brine give the highest hardness of 701. $1 \mathrm{HV}$ with martensitic and pearlite microstructure.
\end{abstract}

Keywords : dodos, heat treatment, quenching media, hardness

\section{PENDAHULUAN}

Dodos merupakan alat yang digunakan pada panen kelapa sawit ketika kelapa sawit pada usia muda yaitu di bawah 5 tahun (atau baru menghasilkan buah) dengan ketinggian rata-rata 3 meter. Perkakas tersebut berfungsi untuk memotong kelapa sawit dari batang pohon kelapa sawit. Salah satu kualitas yang diperhatikan adalah umur pakai dodos. Umur pakai dipengaruhi oleh perpaduan nilai kekerasan dan ketangguhan. Produsen dodos membuat dodos dari bahan baku baja per daun (baja karbon tinggi, $\mathrm{C}=0,5 \%$ ) yang kemudian diberikan proses penempaan dan kemudian dilakukan proses perlakuan panas (pengerasan) pada kondisi yang tidak terukur. Indonesia merupakan salah satu penghasil (produsen) minyak kelapa sawit terbesar di dunia(1). Hal tersebut didukung oleh luas lahan perkebunan yang ada di wilayah Indonesia. Beberapa pulau seperti Sumatera, Kalimantan dan Sulawesi merupakan pulau-pulau yang memiliki lahan perkebunan kelapa sawit yang luas. Di pulau Kalimantan, pada tahun 2004 tercatat luas lahan perkebunan yang tersedia seluas $10,6 \%$ dari total luas wilayah yang tersebar di seluruh pulau di Indonesia(2). Luas lahan perkebunan di pulau Kalimantan tersebut merupakan luas lahan terbesar ke-2 setelah pulau Sumatera.

Industri minyak kelapa sawit sebagai industri yang strategis perlu ditopang oleh industri kelapa sawit dan industri lainnya. Salah satu industri lainnya yang harus menopang pertumbuhan industri kelapa sawit adalah industri perkakas logam (alat pertanian) yang tersebar di sekitar industri kelapa sawit. Pertumbuhan industri kelapa sawit perlu diimbangi oleh industri perkakas alat pertanian yang memadai. Salah satu industri perkakas pertanian yang perlu dijaga kualitasnya adalah industri pembuat dodos.

Jumlah penggunaan dodos dalam panen kelapa sawit akan berdampak pada biaya produksi industri kelapa sawit. Semakin banyak dodos yang digunakan maka akan meningkatkan biaya produksi. Jumlah dodos yang digunakan dipengaruhi oleh umur pakai dari dodos tersebut.

Produsen alat pertanian dodos di pulau Kalimantan telah mampu memproduksi dodos sesuai kebutuhan industri kelapa sawit di pulau Kalimantan. Namun permasalahannya adalah umur pakai dodos yang diproduksi oleh industri lokal belum di bawah umur pakai dodos yang diproduksi oleh produsen dari 
Malaysia. Dodos yang diproduksi oleh industri lokal di Kalimantan dan sekitarnya memiliki umur pakai yang lebih pendek daripada dodos yang diproduksi oleh industri kecil di Malaysia. Kondisi ini membuat industri kelapa sawit lebih memilih untuk menggunakan dodos produksi Malaysia sehingga daya serap dodos produksi industri lokal menjadi menurun. Umur pakai menjadi salah satu karateristik yang penting bagi industri kelapa sawit karena dengan dodos yang memiliki umur pakai yang lebih lama maka akan menurunkan biaya untuk membeli dodos yang baru.

Umur pakai ditentukan oleh perpaduan sifat kekerasan dan ketangguhan. Dodos perlu memiliki nilai kekerasan yang optimal yang didukung oleh nilai ketangguhan yang optimal. Nilai kekerasan yang terlalu tinggi juga tidak baik karena menyebabkan dodos getas (mudah patah). Dodos perlu memiliki kekerasan yang memadai untuk memotong batang kelapa sawit tanpa menyebabkan dodos mudah aus atau patah.

Industri lokal masih menggunakan metode pembuatan dodos yang belum terukur dengan baik. Baja per daun sebagai bahan baku pembuatan dodos ditempa pada temperatur tertentu hingga mencapai bentuk yang diinginkan. Kemudian dodos dipanaskan dengan media arang pada suatu temperatur tertentu dan kemudian didinginkan dengan cepat. Cara pembuatan tersebut belum dapat menghasilkan dodos dengan kualitas yang optimum. Hal ini menjadi salah satu penyebab kualitas (umur pakai) dodos yang dihasilkan tidak sebaik kualitas dodos yang dihasilkan oleh industri kecil di Malaysia.

\section{TINJAUAN PUSTAKA}

Metode pembuatan dodos yang terukur dapat meningkatkan umur pakai dodos. Umur pakai dodos dapat ditingkatkan dengan meningkatkan nilai kekerasannya. Nilai kekerasan ditingkatkan melalui proses pendinginan cepat (quenching). Nilai kekerasan yang dicapai dipengaruhi oleh temperatur austenisasi, lama penahanan pemanasan (holding time) dan media pendinginan cepat (quenching). Melalui perlakuan panas dengan parameter yang terukur diharapkan terbentuk martensite yang bersifat keras-rapuh.

\section{Temperatur Austenisasi}

Pada diagram fasa, untuk baja karbon tinggi yaitu baja dengan kadar karbon antar 0,5 sampai $2 \%$, wilayah austenit ada pada kisaran temperatur $723-900^{\circ} \mathrm{C}$. Untuk mendapatkan fasa martensit dengan proses pendinginan cepat, baja dengan komposisi $0,5 \%$ karbon dipanaskan sampai temperatur di atas garis $\mathrm{A} 1$ (di atas dari $723^{\circ} \mathrm{C}$ ). Fasa martensit yang terbentuk tergantung dari fasa austenit yang ada sebelum dilakukan pendinginan cepat.

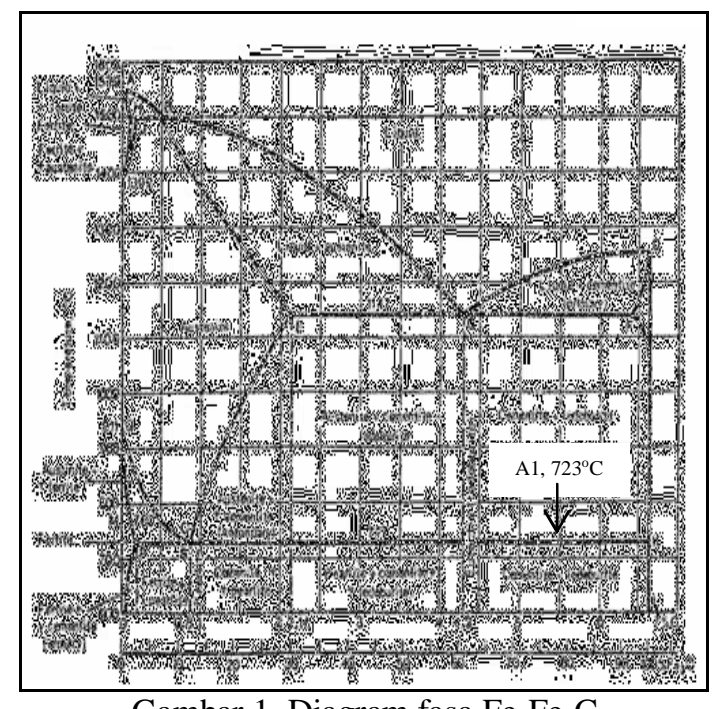

Gambar 1. Diagram fasa $\mathrm{Fe}-\mathrm{Fe}_{3} \mathrm{C}$

Sumber: www.keytometals.com, 30 Juni 2014

Pada penelitian sebelumnya telah dilakukan proses perlakuan panas dengan temperatur austenisasi pada $800^{\circ} \mathrm{C}$, waktu penahanan 30 menit dan pendinginan cepat pada oli(3). Pada temperatur austenisasi $800^{\circ} \mathrm{C}$, kekerasan dodos dapat ditingkatkan.

Untuk mengetahui parameter optimal untuk meningkatkan kekerasan dodos maka pada penelitian ini menggunakan 3 variasi temperatur yaitu 700,800 dan $900^{\circ} \mathrm{C}$. Dalam perlakuan panas baja, temperatur austenisasi tidak perlu lebih dari $900^{\circ} \mathrm{C}$ sehingga pada penelitian ini menggunakan variasi temperatur paling tinggi pada $900^{\circ} \mathrm{C}$.

Temperatur terendah pada penelitian ini adalah pada $700^{\circ} \mathrm{C}$. Walaupun pada diagram fasa dapat diketahui bahwa pada temperatur $700^{\circ} \mathrm{C}$ belum masuk ke fasa austenit sehingga diperkirakan setelah pendinginan cepat tidak akan terbentuk fase martensite. Temperatur tersebut digunakan untuk melihat strukur mikro yang terbentuk dan kekerasan yang dihasilkan. 


\section{Waktu Penahanan}

Secara umum lamanya waktu penahanan dipengaruhi oleh tebal spesimen atau benda kerja. Pada saat penahanan temperatur terjadi homogenisasi panas ke seluruh permukaan dan sub permukaan benda sehingga terbentuk fasa yang homogen. Oleh karena itu, semakin tebal spesimen maka dibutuhkan waktu penahanan yang semakin lama.

Selain dipengaruhi oleh ketebalan benda, lamanya waktu penahanan tergantung pada jenis material yang digunakan. Secara umum untuk material low alloy steel dapat menggunakan pendekatan ketebalan benda yaitu 0,5 menit per millimeter benda. Untuk baja karbon medium, waktu penahanan dianjurkan 15-25 menit(4).

Spesimen yang digunakan pada penelitian ini adalah baja karbon tinggi dengan tebal yaitu sekitar $1 \mathrm{~mm}$ dimana waktu penahanan diasumsikan konstan untuk semua variasi temperatur yaitu selama 60 menit. Pada penelitian lain yang telah dilakukan, austenisasi pada temperatur $800^{\circ} \mathrm{C}$ dengan waktu penahanan 30,60 dan 120 menit dengan oli sebagai media quenching, didapatkan spesimen mengalami retak pada waktu penahanan 60 dan 120 menit(3). Untuk waktu penahan 30 menit tidak terjadi keretakan dan kekerasan spesimen mengalami peningkatan.

\section{Laju Pendinginan}

Struktur martensit merupakan struktur berbentuk jarum yang memiliki sifat keras dan getas dan memiliki sifat ketahanan aus yang baik. Hal tersebut karena proses transformasi secara mekanik (geser) akibat adanya atom karbon yang terperangkap pada struktur kristal pada saat terjadi transformasi polymorfi dari FCC ke BCC. Akibatnya terjadi distorsi kisi kristal BCC menjadi BCT. Distorsi kisi akibat transformasi pada pendinginan cepat tersebut berbanding lurus dengan jumlah atom karbon terlarut(3).

Untuk mendapatkan fasa martensit, pendinginan harus dilakukan secepat mungkin dari temperatur austenit ke temperatur kamar. Media yang umum digunakan adalah udara, larutan garam (brine), air dan oli.

Tiap jenis media quenching akan memberikan laju pendingin yang berbeda. Larutan garam dan air pada temperatur kamar memberikan laju pendinginan yang tercepat. Oli menghasilkan laju pendinginan yang lebih lambat(5) (Gambar 2). Kekerasan yang dihasilkan akan dipengaruhi oleh laju pendinginan tersebut. Oleh karena itu, secara umum larutan garam dan air akan menghasilkan spesimen dengan kekerasan yang lebih tinggi daripada oli.

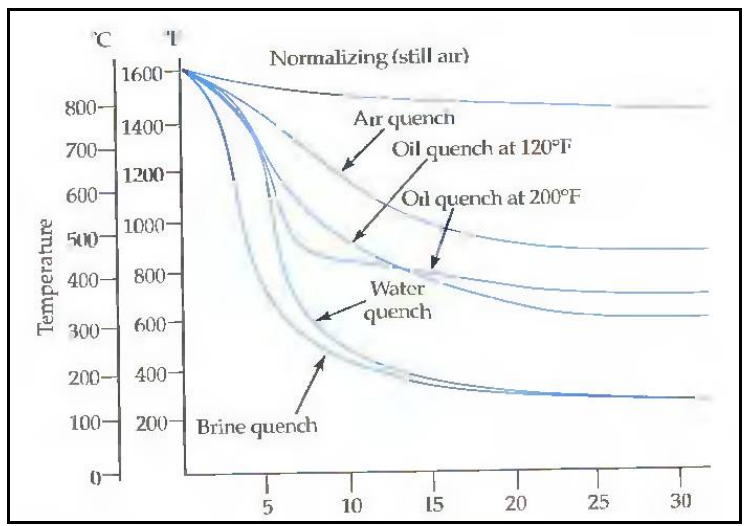

Gambar 2. Perbandingan jenis media quenching terhadap laju pendinginan

Sumber : Brandt, Daniel A. \& Warner, J.C., 2005.

Metallurgy Fundamentals, Goodheart-Wilcox Company, Inc, Amerika

\section{METODE PENELITIAN}

Penelitian ini dilakukan untuk mengetahui parameter (temperatur austenisasi dan media quenching) optimum untuk mencapai nilai kekerasan yang lebih tinggi dari produk dodos yang telah dibuat oleh industri lokal di daerah Kalimantan. Parameter optimum yang didapat akan menjadi acuan untuk meningkatkan kualitas produk dodos yang diproduksi oleh industri lokal. Penelitian dilakukan di Balai Besar Logam dan Mesin sejak Oktober 2013 sampai dengan April 2014.

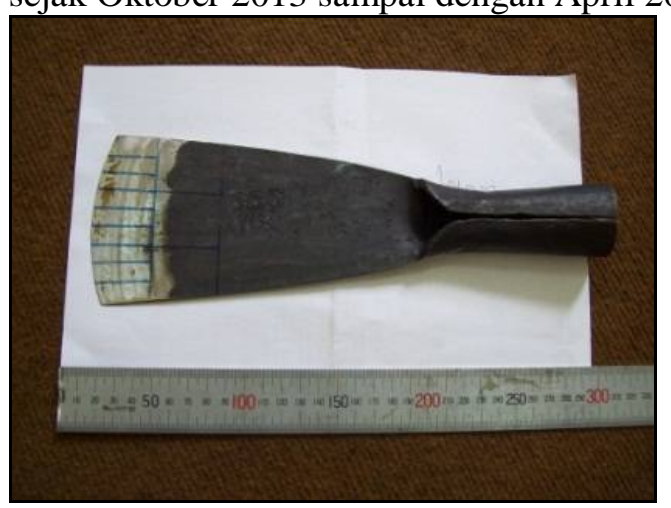

Gambar 3. Foto produk dodos

Spesimen penelitian ini adalah dodos buatan industri lokal Kalimantan sebelum diberikan perlakuan panas (Gambar 3). Spesimen tersebut diambil dari industri lokal di Kalimantan. Bagian ujung dodos tersebut dipotong menjadi beberapa bagian. Lalu 
dilakukan uji komposisi dengan spektrometer untuk mengetahui komposisi material dan uji keras untuk mengetahui kekerasan dodos sebelum diberikan perlakuan panas. Dan kemudian potongan-potongan tersebut diberikan perlakuan panas sesuai parameter penelitian.

Perlakuan panas diberikan dengan variasi temperatur dan media quenching (laju pendinginan). Spesimen dipanaskan dari temperatur kamar sampai pada temperatur 700, 800 dan $900^{\circ} \mathrm{C}$ dan ditahan selama 60 menit. Kemudian masing-masing spesimen pada variasi temperatur tersebut didinginkan cepat pada media larutan garam, air dan oli.

Selanjutnya dilakukan pengujian kekerasan dan pengamatan strutur mikro. Uji kekerasan dilakukan menggunakan metode Mikro Vickers. Dan dari setiap spesimen dilakukan pengamatan struktur mikro pada perbesaran 400X etsa nital 5\%.

\section{HASIL \& PEMBAHASAN}

\section{Komposisi Kimia}

Pengujian komposisi dengan hasil seperti pada Tabel 1 sebagai berikut:

Tabel 1. Komposisi dodos

\begin{tabular}{|c|c|c|c|}
\hline Unsur & $\%$ & Unsur & $\%$ \\
\hline $\mathrm{Fe}$ & 97.010 & $\mathrm{Co}$ & 0.012 \\
\hline $\mathrm{C}$ & 0.671 & $\mathrm{Cu}$ & 0.114 \\
\hline $\mathrm{Si}$ & 0.234 & $\mathrm{Nb}$ & $<0.002$ \\
\hline $\mathrm{Mn}$ & 0.904 & $\mathrm{Sn}$ & 0.012 \\
\hline $\mathrm{P}$ & 0.022 & $\mathrm{Ti}$ & $<0.001$ \\
\hline $\mathrm{S}$ & 0.018 & $\mathrm{~V}$ & 0.028 \\
\hline $\mathrm{Cr}$ & 0.782 & $\mathrm{~W}$ & $<0.005$ \\
\hline $\mathrm{Mo}$ & 0.016 & $\mathrm{Ca}$ & $<0.0003$ \\
\hline $\mathrm{Ni}$ & 0.061 & $\mathrm{~Pb}$ & $<0.001$ \\
\hline $\mathrm{Al}$ & 0.010 & $\mathrm{Zn}$ & 0.001 \\
\hline $\mathrm{B}$ & 0.0008 & & \\
\hline
\end{tabular}

Dari Tabel 1 diketahui bahwa bahan baku dodos memiliki kandungan karbon sebesar $0,671 \%$ sehingga termasuk dalam baja karbon tinggi(6). Berdasarkan klasifikasi tersebut, bahan baku produk dodos tersebut diperkirakan sudah memiliki kekerasan yang lebih tinggi dibandingkan baja karbon medium dan baja karbon rendah. Pada penelitian lainnya, baja sekitar $0,5 \% \mathrm{C}$ kekerasan dodos loka dan dodos impor adalah $270 \mathrm{HV}$ dan 670 HV(3). Dengan komposisi karbon 0,671\% (lebih besar dari 0,5\%C), umumnya kekerasan akan lebih tinggi.

\section{Uji keras}

Hasil uji keras untuk spesimen dodos yang belum diberikan perlakuan panas yaitu 320 HV. Dan nilai kekerasan untuk spesimen yang telah diberikan perlakuan panas dan pendinginan cepat dapat dilihat pada Tabel 2 dan Gambar 3. Dari grafik tersebut dapat dilihat bahwa nilai kekerasan untuk spesimen yang belum mengalami proses perlakuan panas memiliki nilai kekerasan mendekati nilai kekerasan setelah dipanaskan pada temperatur $700^{\circ} \mathrm{C}$ dengan media larutan garam, air dan oli. Tidak ada peningkatan nilai kekerasan dari spesimen sebelum diberikan perlakuan panas dan setelah diberikan perlakuan panas. Hal ini disebabkan karena pada temperatur $700^{\circ} \mathrm{C}$ belum mencapai daerah fasa austenit sehingga pada saat diberikan pendinginan cepat tidak terbentuk fasa martensit yang memiliki sifat keras. Nilai kekerasan meningkat hampir 2 kali lipat pada temperatur austenisasi 800 dan $900^{\circ} \mathrm{C}$ dari temperatur $700^{\circ} \mathrm{C}$.

Tabel 2. Hasil uji kekerasan terhadap temperatur austenisasi dan media quenching

\begin{tabular}{|c|c|l|c|}
\hline No. & $\begin{array}{c}\text { Temp. } \\
{ }^{\circ} \mathrm{C}\end{array}$ & Media & $\begin{array}{c}\text { Kekerasan } \\
\text { HV }\end{array}$ \\
\hline 1. & 0 & Non HT & 320 \\
\hline 2. & 700 & $\begin{array}{l}\text { Larutan } \\
\text { garam }\end{array}$ & 312.5 \\
\hline 3. & 700 & Air & 295.1 \\
\hline 4. & 700 & Oli & 283.7 \\
\hline 5. & 800 & $\begin{array}{l}\text { Larutan } \\
\text { garam }\end{array}$ & 528.9 \\
\hline 6. & 800 & Air & 617.2 \\
\hline 7. & 800 & Oli & 624.7 \\
\hline 8. & 900 & $\begin{array}{l}\text { Larutan } \\
\text { garam }\end{array}$ & 701.1 \\
\hline 9. & 900 & Air & 583.4 \\
\hline 10. & 900 & Oli & 665.2 \\
\hline
\end{tabular}




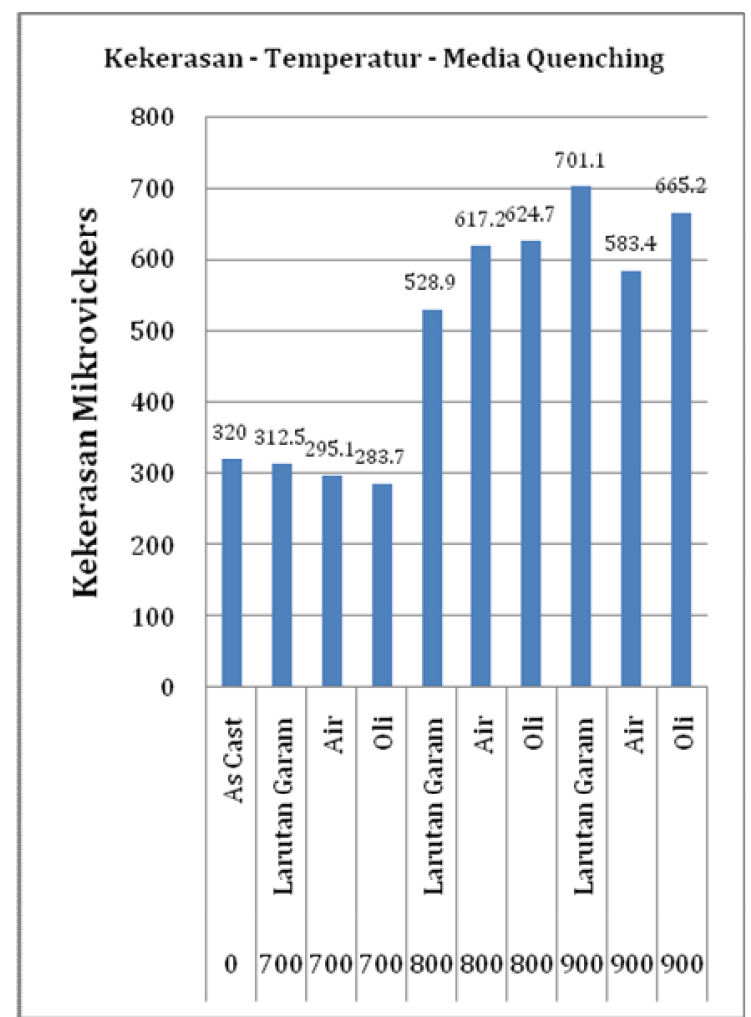

Gambar 3. Grafik kekerasan terhadap temperatur austenisasidan media quenching

Secara umum dengan meningkatkan temperatur austenisasi maka kekerasan akan meningkat. Hal ini dapat terjadi karena pada temperatur austenisasi yang tinggi maka fasa austenit yang terbentuk semakin banyak. Ketika dilakukan proses quenching struktur martensit yang terbentuk semakin banyak. Struktur martensite akan memberikan kekerasan.

Peningkatan nilai kekerasan yang dihasilkan dari media larutan garam, air dan oli memberikan nilai yang bervariasi. Variasi temperatur pemanasan menghasilkan trend yang tidak teratur terhadap nilai kekerasan terhadap media quenching air yaitu 295,1; 617,2 dan 583,4 HV. Tren yang tidak teratur tersebut disebabkan ketidakhomogenan struktur martensit yang terbentuk pada saat proses pendinginan cepat berlangsung.

Nilai kekerasan dengan media quenching larutan garam dan oli memberikan tren nilai kekerasan yang meningkat terhadap peningkatan temperatur pemanasan dan austenisasi. Nilai kekerasan dengan media quenching larutan garam menghasilkan kekerasan 312,5; 528,9; 701,1 HV pada temperatur pemanasan dan temperatur austenisasi 700,800 dan $900^{\circ} \mathrm{C}$. Pada media oli memberikan nilai kekerasan 283,7; 624,7;
665,2 HV. Hal tersebut disebabkan oleh kehomogenan struktur martensit yang terbentuk.

Nilai kekerasan yang paling tinggi yaitu 701,1 HV terjadi pada temperatur austenisasi $900^{\circ} \mathrm{C}$ dan media quenching larutan garam. Nilai kekerasan ini lebih tinggi dibandingkan nilai kekerasan pada penelitian lainnya pada spesimen dodos impor (670 HV) (3). Larutan garam memberikan laju pendinginan lebih cepat dibandingkan air dan oli sehingga menghasilkan struktur martensit yang lebih kasar. Struktur tersebut memberikan kekerasan lebih tinggi.

Nilai kekerasan pada temperatur austenisasi $900^{\circ} \mathrm{C}$ dengan media quenching oli menghasilkan nilaikekerasan yang lebih tinggi dibandingkan pendinginan cepat dengan media air. Walaupun air memberikan laju pendinginan yang lebih cepat daripada oli. Nilai kekerasan dengan media oli dan air adalah 665,2 dan 583,4 HV. Hal ini dapat terjadi karena ketidakhomogenan struktur martensit yang terbetuk dengan media air.

\section{Pengamatan Struktur Mikro}

Pengamatan struktur mikro dilakukan dengan menggunakan mikroskop optik dengan perbesaran 400X dan etsa nital 5\% untuk setiap variasi temperatur dan media pendinginan. Pada spesimen dengan temperatur austenisasi $900^{\circ} \mathrm{C}$ dan media quenching larutan garam (nilai kekerasan tertinggi $=701,1 \mathrm{HV})$, struktur mikro yang terbentuk adalah martensit yang kasar (warna putih) dan perlit (area gelap)(7). Fasa ini terbentuk dari austenit metastabil yang didinginkan dengan laju pendinginan yang sangat cepat (Gambar 4).

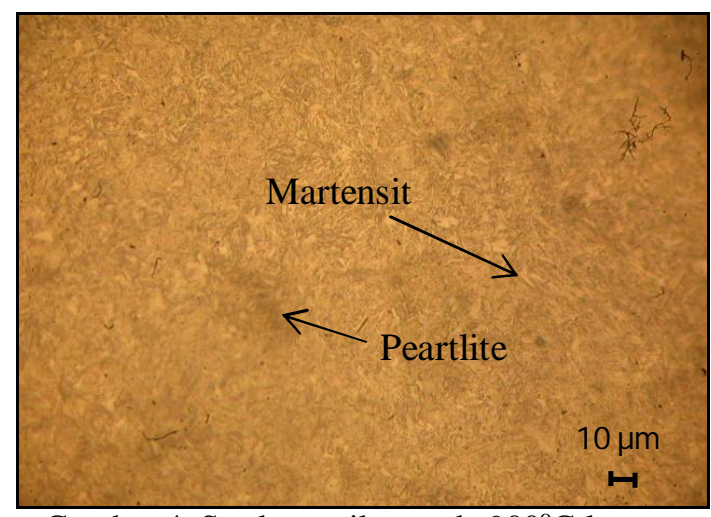

Gambar 4. Struktur mikro pada $900^{\circ} \mathrm{C}$-larutan garam (400X, nital 5\%) 
Struktur mikro pada spesimen dengan temperatur austenisasi $900^{\circ} \mathrm{C}$ dan media quenching oli dengan nilai kekerasan 665,2 HV dapat dilihat pada Gambar 5. Struktur mikro yang terbentuk adalah martensit yang lebih halus (warna putih) dan perlit (area gelap). Nilai kekerasan dengan oli lebih rendah daripada nilai kekerasan dengan larutan garam pada temperatur austenisasi $900^{\circ} \mathrm{C}$. Hal ini karena struktur mikro martensit yang terbentuk dengan media oli lebih halus dan kurang homogen dibandingkan dengan struktur mikro pada media larutan garam.

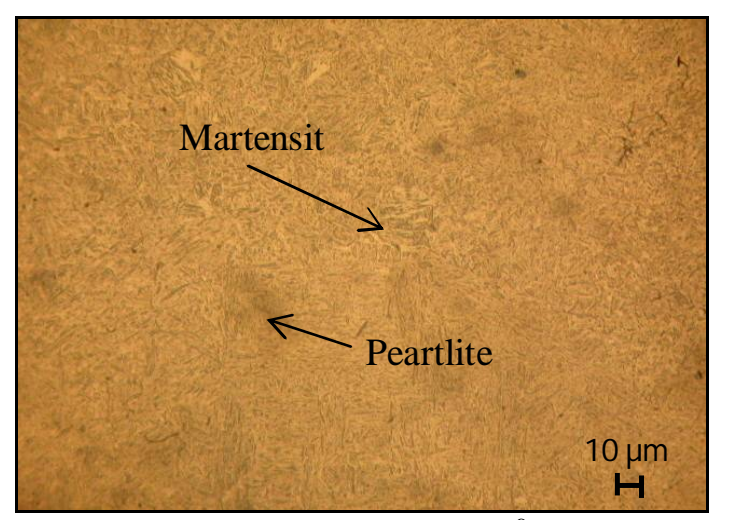

Gambar 5. Struktur mikro pada $900^{\circ} \mathrm{C}$-oli (400X, nital 5\%)

Struktur mikro pada temperatur $900^{\circ} \mathrm{C}$ dengan media air dapat dilihat pada Gambar 6. Struktur mikro yang terbentuk adalah martensit yang kasadan perlit (area gelap). Dibandingkan dengan media larutan garam dan oli, nilai kekerasan dengan media air pada temperatur austenisasi $900^{\circ} \mathrm{C}$ adalah paling rendah yaitu 583,4 HV (larutan garam dan oli adalah 701,1 dan 665,2 HV). Hal tersebut dapat disebabkan oleh ketidakhomogenan struktur yang terbentuk.

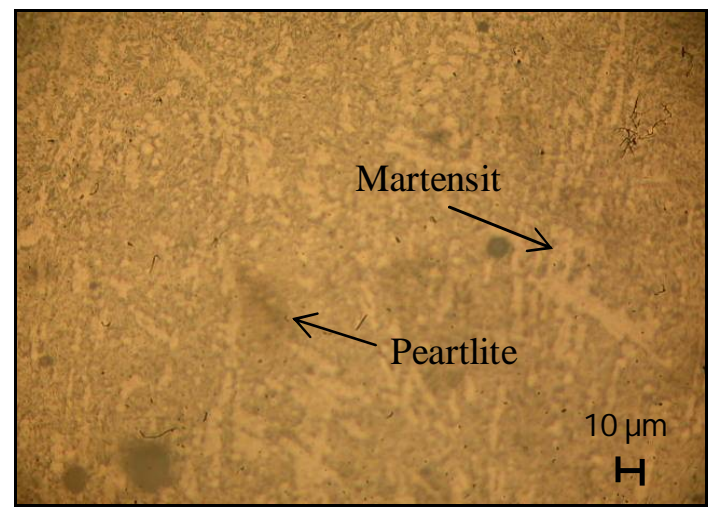

Gambar 6. Struktur mikro pada $900^{\circ} \mathrm{C}$-air (400X, nital 5\%)

\section{KESIMPULAN \& SARAN}

Dari penelitian ini dapat diambil beberapa kesimpulan sebagai berikut:

1. Parameter optimum untuk meningkatkan kekerasan dodos adalah pada temperatur austenisasi $900^{\circ} \mathrm{C}$ dan media quenching larutan garam dimana menghasilkan nilai kekerasan sebesar 701,1 HV (nilai kekerasan dodos impor dari penelitian lain yaitu $670 \mathrm{HV}$ ).

2. Kekerasan dipengaruhi oleh homogenitas struktur martensite yang terbentuk.

3. Perlu menvariasikan perbandingan air dan garam pada larutan air garam untuk mengetahui pengaruhnya terhadap kekerasan optimum.

\section{DAFTAR PUSTAKA}

1. Fransisco, Rosario, 2013. Indonesia Produsen terbesar Minyak Kelapa Sawit, November 2013, www.tempo.com, Bandung, Indonesia.

2. Departemen Perindustrian Indonesia, 2007. Gambaran Sekilas Minyak Kelapa Sawit, hal. 4, Sektretarian Jenderal, Pusat Data dan Informasi, Jakarta, Indonesia.

3. Suherman, et al, 2012. Perbaikan Sifat Fisis dan Mekanis Alat Panen Buah Kelapa Sawit (Egrek dan Dodos) Produk Lokal, Jurnal Dinamis volume 1 nomor 11, Universitas Sumatera Utara, Indonesia.

4. Effendi, Sairul, 2009. Pengaruh Perbedaan Waktu Penahanan Suhu Stabil terhadap Kekerasan Logam, Jurnal Austenit, Teknik Mesin Politeknik Negeri Sriwijawa, Indonesia.

5. Brandt, Daniel A. \& Warner, J.C., 2005. Metallurgy Fundamentals, p. 171, Goodheart-Wilcox Company, Inc, Amerika.

6. ASM Handbook volume 1, 2005. Properties and Selection: Irons, Steels and High Performance Alloys Section, ASM International, Amerika.

7. ASM Handbook volume 9, 2004. Metallography and Microstructures, ASM International, Amerika.

8. Suyanto, Irham, 2007. Pengaruh Tipe Pengerasan terhadap Distribusi Kekerasan, Kedalam Difusi dan Struktur Mikro Baja Karbon Rendah (Mild Steel) yang Telah Dikarburisasi, Jurnal Ilmiah Semesta Teknika, Volume 46 Nomor 1 Tahun 2007, Surabaya, Indonesia. 
9. Mizhar, Susri dan Suherman, 2011. Pengaruh Perbedaan Kondisi Tempering terhadap Struktur Mikro dan Kekerasan dari Baja AISI 4140, Jurnal Dinamis Volume II Nomor 8 Januari 2011, Medan, Indonesia.

10. Lan, Liangyun, et al, 2011. Analysis of martensite-austenite constituent and its effect on toughness in submerged arc welded joint of low carbon bainitic steel, $\mathrm{J}$ Master Sci (2012), Springer Science+Business Media, LLC 2012.
11. J. Chakraborty, P.P, et al, 2010. Microstructural Refinement of Bainite and Martensite for Enhanced Strength and Toughness in High-Carbon LowAlloy Steel, The Minerals, Metals \& Material Society and ASM International 2010. 